\title{
Hières-sur-Amby - Marignieu, route de Beauchêne
} $n^{\circ} 2211313$

Daniel Frascone

\section{(2) OpenEdition}

Édition électronique

URL : http://journals.openedition.org/adlfi/15083

ISSN : 2114-0502

Éditeur

Ministère de la culture

Référence électronique

Daniel Frascone, « Hières-sur-Amby - Marignieu, route de Beauchêne », ADLFI. Archéologie de la France - Informations [En ligne], Rhône-Alpes, mis en ligne le 30 juillet 2015, consulté le 02 mai 2019. URL http://journals.openedition.org/adlfi/15083

Ce document a été généré automatiquement le 2 mai 2019.

(c) Ministère de la Culture et de la Communication, CNRS 


\section{Hières-sur-Amby - Marignieu, route de Beauchêne}

$n^{\circ} 2211313$

Daniel Frascone

Lien Atlas (MCC) :

http://atlas.patrimoines.culture.fr/atlas/trunk/index.php?

ap_theme=DOM_2.01.02\&ap_bbox=5.267;45.780;5.316;45.822

Quatre sondages ont été réalisés sur les parcelles sondées. Hormis une couche épaisse contenant des déchets de taille ou de démolition de maçonnerie ainsi que des fragments de tegulae, dans le sondage situé en limite sud, aucune trace d'occupation n'a été observée.

INDEX

Index géographique : Rhône-Alpes, Isère (38), Hières-sur-Amby

Mots-clés : tegula

\section{AUTEURS}

DANIEL FRASCONE

Inrap 